\title{
Lack of Actor in the State Address of Indonesian President on the 74th Indonesia Independence Day
}

\author{
Jonathan Irene Sartika Dewi Max \& Mardliya Pratiwi Zamruddin \\ irenesartika@fib.unmul.ac.id, mardliyapratiwi@fib.unmul.ac.id \\ English Literature Study Program, Mulawarman University, INDONESIA
}

\begin{abstract}
Political speech must be perceived critically in order to avoid the misuse of power. Applying Systemic Functional Linguistics (SFL) and Critical Discourse Analysis (CDA), this paper offered a perspective to understand how power is symbolically exercised through the use of language in Jokowi's State Address on the occasion of 74th Indonesia Independence Day 2019. The analysis started by collecting the clauses with high modulation represented by the modal word 'must'. It appeared as the most frequent modal in the speech text indicating that there is an act of commanding given by the President. However, the high modulated clauses did not give a clear guide on who is the liable Actor for the realization of the discourse of an "Advanced Indonesia". This phenomenon in language was critical to show that there was a possibility of symbolic violence, which happens because of speaker/writer did not clearly state who was the responsible Actor for each specific action required in the discourse of an Advanced Indonesia. In this instance, his speech opens the possibility of symbolic violence. This was proven by 1) the unidentified accountable Actor from the use of the pronoun 'we', 2) hidden agent in nominalization in the Material process, 3) the use of passive voice with Material Process, and 4) the process of Relational Process of Attributive used for characterizing Indonesia.
\end{abstract}

Article information

Keywords: Actor; CDA; SFL; Modality

DOI: 10.24071/joll.v20i2.2632

Available at https://e-journal.usd.ac.id/index.php/JOLL/index

This work is licensed under a Creative Commons Attribute-ShareAlike 4.0 International License

\section{Introduction}

Anytime language is used for communicating, language user is attempting to do something. The actions implied by the use of language, according to Gee, vary from informing, persuading, encouraging, requesting, denying, praising, to bonding. The choice made both in writing or speaking forms is the way of acting (Gee, 2018, p. 139). Gee further says that "we use language to get recognized as taking on a certain identity or role, that is, to build an identity here and now" (Gee, 2014, p. 95).

This paper discusses a speech delivered by President Jokowi in the moment of the $74^{\text {th }}$ Anniversary of the Proclamation of Independence of the Republic of Indonesia before the Joint Session of the Regional Representatives Council of the Republic of Indonesia and the House of Representatives of the Republic of Indonesia. It is the first state address delivered after Jokowi won the election for the second period, and on the same 
occasion, he announced the relocation of Indonesia capital to East Borneo.

Jokowi constructs the discourse of Advanced Indonesia in his speech, which goes beyond the use of sentences. Discourse, according to Hart, is not just a matter of "linguistic practice but a social practice which gives to the formation of the social systems, situations, institutions, and ideologies in which it is embedded" (Hart, 2014, p. 3). To use language means to act out a role that is already attached to the person and defined by the social convention among the language users. In such a convention, power relation works circularly. However, power can be made less detectable or misrecognized as a result of language use and symbolic forms. (Bourdieu, 1977 in Loyal 2017, p. 32). Loyal adds that "Symbolic power is a power of making people see the social world in a specific way, of creating a vision of divisions that affirms or transforms the vision of the world that social agents posses, and therefore the social world itself" (2017, p. 33).

For "the power of language is vested in the act of meaning" (Halliday, 1992 in Webster (ed.) 2003, p. 375), it is important to track the meanings being created in such political speech. Here, Hallidayan approach of Systemic Functional Linguistics (SFL) is applied within a Critical Discourse Analysis (CDA) perspective, which aims to empower society (Wodak, 2000 ) by the awareness of the way language is used to achieve the goal of the speaker.

A former study which has done a similar approach to discover the implication of a political speech is Ideologies in Hosni Mubarak's and Muammar Qaddafi's Translated Speeches: Critical Discourse Analysis written by Arina Isti'anah (2012). By comparing the translated speeches of Hosni Mubarak's and Muammar Qaddafi, she reveals the different ideological standpoints of both figures using Hallidayan SFL. The finding is that Mubarak's speech displays the quality of sacrifice, optimism, and appreciation while Qaddafi's speech displays the tone of provocation, volunteer, and pride.

The other study on political speech is done by Nova Anggraini (2018) entitled Transitivity
Process And Ideological Construction Of Donald Trump's Speeches. She uses the transitivity analysis to reveal that Donald Trump constructs democracy view in speeches and from the strong consistency is considered as a persuasive strategy to convince American people to support him in his government.

The third research discussing language, power, and ideology is entitled $A$ Critical Discourse Analysis of Kim Namjoon's Speech written by Uswatun Hasanah, Alek Alek, and Didin Nuruddin Hidayat (2019). They analyze types of Transitivity Processes and tenses in the modality to prove that Kim Namjoon with her speech tries to create an intimacy with the audience.

Different from the three previous studies that focus only on the types of the Transitivity Processes, this research focuses more on the Modality as it is combined with certain Transitivity Process in the speech text. It means that not only the implication of the Modalization use that will be scrutinized but also the Participants that follow in the process types which then, are considered important to the Interpersonal Meaning and the realization of the discourse done by the speaker. The findings of this paper reveal how President Jokowi exercising the power within the discourse through his choice of language features. His speech opens a possibility of symbolic violence by having no specific Actor on the actions described as important issues in achieving an Advanced Indonesia.

\section{Methodology}

The use of text is a social practice (Meurer, 2004, p. 87). The state address, in this instance, is a form of social practice. The use of SFL to the discourse serves in revealing the commodity exchange in communication and transitivity is as an ideational source of meaning which provides the ground of interpreting the text in the framework of CDA. Text, as Fairclough states, simultaneously identifies social Actors, which has a contribution to the constitution of social and personal identities (2010, p. 75).

Halliday, as cited in Fairclough (2003, p.27), argues that Systemic Functional 
Linguistics, for instance, claims that texts simultaneously have ideational', 'interpersonal' and 'textual' functions (Halliday 1978, 1994). The data of this research was the President's state address, which was taken from the official website of the office of Assistant to Deputy Cabinet Secretary for State Documents \& Translation published on August 16, 2019. The data were given code ' $E$ ' for the excerpt from each sentence that is taken as the data for this research.

This research follows five common features in CDA by Norman Fairclough and Ruth Wodak compiled by Jorgensen (2004, pp. 61-64). First is the view that the character of social and cultural processes and structure is partly linguistic-discursive. Second is that discourse is both constitutive and constituted. Third, it is said that language use should be empirically analyzed. Fourth is that discourse functions ideologically. The fifth is the need to develop critical research, which means that doing CDA is not supposed to be politically neutral. As a critical approach, the researcher is politically committed to social change. This research brings the value of emancipatory, which means that this research takes the side of the oppressed social groups.

This research was done in some stages from the functional analysis to the interpretation given in the Critical Discourse Analysis framework. The first stage was done with close reading to grasp the overall theme of Jokowi's State Address. The second was to count the occurrence of words in sentence rank with a software Simple concordance Program Version 4.0.9. The third stage was done by limiting the functional analysis to the clause appear with the high modulation 'must', and the last stage was done by interpreting the findings from functional analysis within the framework of CDA.

The data of this research was the English version President's state address which was directly taken from the official website of the office of Assistant to Deputy Cabinet Secretary for State Documents \& Translation published on August 16, 2019. The data were given code ' $E$ ' for the excerpt from each sentence that is taken as the data for this research.

\section{Results and Discussion \\ The Discourse of Jokowi's Indonesia Independence Day State Address}

From the close reading, the researchers have gained a general look at the topic of the speech delivered by Jokowi in the Indonesia Independence Day 2019. He starts by describing Indonesia as an Advanced Country (Negara Maju), which is mentioned as the result of the work of many parties.

An advanced Indonesia is not only the work of the President and the Vice President, not only the work of the executive, legislative, or judiciary. In fact, the success Indonesia has achieved is also the work of religious leaders, cultural figures, and educators. Indonesia's success is also the work of businessmen, labors, traders, innovators, as well as farmers, fishermen, and micro, small, and medium enterprises (SMES) Actors, and the work of the entire children of the nation. (Jokowi's Indonesia Independence Day State Address, 2019, Paragraph 2)

Then, he continues by defining the challenges an advanced Indonesia would face. First is the competition fueled by the Industrial Revolution 4.0. on technology development across countries (Par. 5). The second is the threat to Pancasila as Indonesia Ideology caused by the flows of information that is more open to new ideas that may risk the conduct and manner, traditions, arts, cultures, and local pearls of wisdom (Par. 7). Third are cyberwar, intolerance, radicalism, and terrorism (Par. 8). All of these are seen as an anendangerment to Indonesia's defense and security. Fourth is the global trade competition over market and investment. The fifth challenge is Ring of Fire that causes unpredictable catastrophe and so are other disasters like forest fires and floods (Par. 14).

He pursues to solve those challenges by offering several prescribed acts that are required to achieve an Advanced Indonesia. He attempts to touch several major fields that are needed to be maintained to match the purposes. First is in the field of science and technology that should be innovated for ease and speed (Par. 16). The second is to manage the need for natural resources by building downstream industries to cut imports (Par. 
18). The third is the education field, which according to him, needs a massive overhaul prioritizing the vocational high school and developing teacher's competence to face global changes (Par. 22-23).

The fourth is the importance of deregulation, which means for debureaucratization, simplifying working procedures and services, and maintaining consistency of regulation. This aspect includes legislative reform, which means to erase incompatible, inconsistent, and overlapping regulations (Par. 25). He also says that the performance measurement of legislators must be measured by how much the regulation is made to protect the interest of the people and the nation to make it easy to achieve the goals. Besides, he mentions about Corruption Eradication Officers whose performance, in his view, must not be measured by the number of the people sent to jails but from the effort of prevention to state loss potential so that the governance and the system are the matters to be developed (Par. 32).

The fifth is about the budget realization, which must be measured by the products/services it can provide to people (Par. 34). The sixth focus is the adoption of the newest technology to simplify the work of the organization and to cut inefficient and irrelevant apparatus (Par. 35).

In this historic occasion, while asking for the blessings and grace of Allah subhanahu wa'taala and blessings and supports from the distinguished members of the House of Representatives and members of the Regional Representatives Council, our national leaders, our national figures, and especially the whole Indonesian people, allow me to relocate our capital to the island of Kalimantan. A capital not only is a symbol of national identity but also represents the advancement of the nation. This move aims to create economic justice and equitability. This move aims to achieve the vision of an Advanced Indonesia Indonesia that lasts forever. (Jokowi's Indonesia Independence Day State Address, 2019: Paragraph 38)
All of these solutions, he says, must be supported by all state apparatus without exception. Nonetheless, he closes his speech announcing that the capital of Indonesia is being relocated to Kalimantan island for the capital, for him, represents the advancement of the nation.

\section{The Functional Analysis of Jokowi's Indonesia Independence Day State Address}

The description of the finding only talks about the clause that appears with High Modulation. This is meant to limit the interpretation only on the most urgent issues taken in the speech, which are characterized by the High Modality that is used the most frequently in the text. The High Modulation is represented by the modal word 'must' which appears 74 times. The other Modulation is represented by the modal word 'can (17x), 'will' (7x), and should (1x). So from the total (99x) modal words that appear, 'must' occur at $75 \%$ of all types of modal (in Bahasa Indonesia version, the word parallel to 'must', 'harus' occurs $81 \mathrm{x}$ throughout the speech). Lise Fontaine (2013, p. 120) quotes Halliday and Matthiessen (1999, p. 526) emphasizes that modality serves as the resource to see how speakers intrude their own views into the discourse in the way they assess the discourse, judge the rights and wrongs of the situation, or where the people stand on the matter.

This data already shows that in this speech, Jokowi prefers to use a 'commanding' style of speaking even though it is not always clearly heard because it is wrapped in declarative sentences that sound more 'giving information' than the direct 'imperative sentence'. However, in the SFL, where language functions are taken on the semantic level of meaning, those 'must's clearly should be considered as 'Command'. The command, if it is seen in the term of Commodity Exchange, implies the meaning of the Demanding of Goods and Services (Eggins, 2004, p. 146).

By demanding Goods and Services, Jokowi exercises his power as the country leader. However, the discourse that he builds by doing so must be seen from the other parts of the clauses which are the participants. 


\section{Question on the Agents 'We' in the Material Process}

Gee (2018, p. 64) notes that subjects often even though not always "name an agent (Actor) in action."The speech delivered by
Jokowi uses 32x of the pattern 'We+Must+V' which means the agent in the actions wished to be taken is "we". As Actor 'we' is predicated with Material Processes showing the actions that are embedded to the subject of the clause.

Table 4. Must + Material Process (Active Sentence, We as Actor)

\begin{tabular}{|c|c|l|l|}
\hline $\begin{array}{c}\text { Actor } \\
\text { (Agent) }\end{array}$ & Modal & Material Processes & \multicolumn{1}{|c|}{ Goal } \\
\hline We & Must & $\begin{array}{l}\text { capitalize, face, } \\
\text { abandon, devise, } \\
\text { adopt, act, do, move, } \\
\text { continue, increase, } \\
\text { develop, strengthen, } \\
\text { mitigate, prepare, } \\
\text { muster, achieve, do, } \\
\text { expand, improve, } \\
\text { safeguard, reduce, } \\
\text { widen, simplify, } \\
\text { make, carry out, stop, } \\
\text { regulate, go abroad }\end{array}$ & $\begin{array}{l}\text { low the flow of communication and interaction that are } \\
\text { now increasingly easier and more open, the openness, } \\
\text { competition, uncompetitive old ways, new strategies, } \\
\text { new ways, our contribution, an initiative of } \\
\text { collaboration and cooperation, our capacity, } \\
\text { unpredictable natural disasters, infrastructure, The } \\
\text { courage, capacity of our educator, the large budget } \\
\text { allocation on education, stunting cases, access to } \\
\text { health services, health quality, de-bureaucratization, } \\
\text { working procedures, processes, technology, legislative } \\
\text { reforms, new threats, the adoption of technology }\end{array}$ \\
\hline
\end{tabular}

As the highly modulated clauses that imply command from the President, there are a lot to be acted out by the Actor 'we'. However, the word 'we' in English really needs a careful interpretation because it is not directly showing whether the 'we' is exclusive or inclusive. The researchers consult the Bahasa Indonesia version and find out that the 'we' applied here is the inclusive (kita) one. Putting the inclusive 'we' is a way to personate a close relationship between the speaker and the hearer. This is also a way to realize an interpersonal meaning, which means that the president offers himself as part of the action.

On the other hand, a country is built by many constituents. Apart from the common style of political speech that tries to gain as many as support from the addressees, without clearly stating the party who is responsible for each matter, such manner opens a chance to the misuse of power.

E1. We must face competition with creativity, innovation, and swiftness that we have.

\begin{tabular}{|l|l|l|l|l|}
\hline We & Must & face & competition & $\begin{array}{l}\text { with creativity, innovation, and swiftness that we } \\
\text { have. }\end{array}$ \\
\hline Mood & Residue & Circ: Enhancing: Manner: Means \\
\hline Actor & $\begin{array}{l}\text { Proc: } \\
\text { Material }\end{array}$ & Goal & (n) \\
\hline
\end{tabular}

E2. In fact, we must face the openness with vigilance, be it against other ideologies that may harm ideology of the nation.

\begin{tabular}{|l|l|l|l|l|l|}
\hline In fact, & We & must & face & $\begin{array}{l}\text { the } \\
\text { openness }\end{array}$ & $\begin{array}{l}\text { with vigilance be it against other ideologies } \\
\text { that may harm ideology of the nation. }\end{array}$ \\
\hline Residue.... & Mood & ...Residue & \multicolumn{3}{|l}{} \\
\hline & Actor & & $\begin{array}{l}\text { Proc: } \\
\text { Material }\end{array}$ & Goal & Circ: Enhancing: Manner: Means \\
\hline
\end{tabular}


Excerpt 1 (E1) for example, the challenge of global competition must be faced by 'we'. Hearers who have no access to the Means 'creativity, innovation, and swiftness' will not feel obligated to face the competition or just simply refuse to be addressed by such responsibility. The same thing applied to E2, those who have not raised 'the awareness' on what is meant by 'harming ideology' will not be compelled to do so.

\section{Hidden Actors in Nominalization}

The process of 'nominalization' becomes a matter in making discourse. Even it is meant to tighten the information, more often it results in obscurity. English morphology allows such derivation forming a verb to a noun. "The verb is the heart and soul of the clause" (Gee, 2018, p. 45). While the verb is 'hidden' in nominalization, the agent (Actor) is also unseen. In Jokowi's speech, the modal 'must' also appears in five ranks where the nouns are put as the subject of the main clause. See the table below:

Table 5. Must + Material Process (Active Sentence, Things as Actor)

\begin{tabular}{|l|l|l|l|}
\hline \multicolumn{1}{|c|}{ Actor (Agent) } & Modal & Material Process & \multicolumn{1}{|c|}{ Goal } \\
\hline $\begin{array}{l}\text { Investment, Regulations, } \\
\text { training centers, quality and } \\
\text { culture of our apparatus }\end{array}$ & must & $\begin{array}{l}\text { Provide, push, } \\
\text { receive, improve }\end{array}$ & $\begin{array}{l}\text { new employment, a sense of } \\
\text { security, ease, everyone, full } \\
\text { supports }\end{array}$ \\
\hline
\end{tabular}

The addressees then must be aware of what the 'hidden clause' (Gee, 2018) implies. In 'investment' $\rightarrow$ there should be an investor and in regulation $\rightarrow$ a regulator. If the real Actors of the matter are not mentioned, again, there is a chance to those who have the obligation to provide the service, to not obey the command. Meanwhile, the rest of the people who have no privilege as investors or regulation makers may put the hope that there will be a realization of the goals in the condition of not knowing the exact provider of new employment and a sense of security.

\section{Hidden Actors in Passive Voice Clauses}

Any use of language deals with an important principle of choice that signals what information a speaker/writer wants the hearer/reader to see as more or less salient (Gee, 2018, p. 61). In Jokowi's speech, he choices to the passive voice over the possibility to utter in an active voice. He chooses to put the Goal as foregrounded while the Actor or Agent is backgrounded. The transitivity system, however, allows the grammatical structure to make such focus possible. Where the Actor is not put in the clause, the Subject/Topic is the Goal. See the table below to see what Goals are in the focus to support his discourse of an 'Advance Indonesia':

Table 6. Modal Must in Passive Voice with Material Process

\begin{tabular}{|c|l|l|l|}
\hline \multicolumn{1}{|c|}{ Actor } & \multicolumn{1}{|c|}{ Modal } & \multicolumn{1}{c|}{ Material Process } & \multicolumn{1}{c|}{ Goal } \\
\hline- & must & $\begin{array}{l}\text { (not) be ignored., be supported., } \\
\text { be removed., be synchronized, } \\
\text { simplified, and trimmed., (not) } \\
\text { be trapped, be eliminated, be } \\
\text { upheld, be protected., be } \\
\text { changed, be encouraged, be } \\
\text { appreciated.be appreciated., be } \\
\text { developed., be dedicated, be } \\
\text { coupled, be merged., be cut. }\end{array}$ & $\begin{array}{l}\text { the mission to participate in } \\
\text { building a better world order, } \\
\text { All of which, Regulations that } \\
\text { are not compatible with the } \\
\text { recent development, } \\
\text { Inconsistent and overlapping } \\
\text { regulations, we Such } \\
\text { regulations, data sovereignty, } \\
\text { Rights of the citizens for }\end{array}$ \\
\hline
\end{tabular}




\begin{tabular}{|l|l|l|}
\hline & $\begin{array}{l}\text { personal data, performance } \\
\text { measurement for the legislators, } \\
\text { performance measurement for } \\
\text { the legislators, Strict law } \\
\text { enforcement, Firm human rights } \\
\text { enforcement, management, } \\
\text { governance, and system, State } \\
\text { budget, Simplifying procedures } \\
\text { and adoption of the latest } \\
\text { technology at works, } \\
\text { Organizations with overlapping } \\
\text { functions, the number of } \\
\text { organizations and the number of } \\
\text { inefficient and irrelevant } \\
\text { apparatus }\end{array}$ \\
\hline
\end{tabular}

Let us discuss some of the statements with these examples:

E3. Regulations that are not compatible with the recent development must be removed.

\begin{tabular}{|l|l|l|}
\hline $\begin{array}{l}\text { Regulations that are not compatible with } \\
\text { the recent development }\end{array}$ & must & be removed. \\
\hline Mood & & Residue \\
\hline Goal & Proc: Material \\
\hline
\end{tabular}

E4. Rights of the citizens for personal data must be protected.

\begin{tabular}{|l|l|l|}
\hline Rights of the citizens for personal data & must & be protected. \\
\hline Mood & & Residue \\
\hline Goal & Proc: Material \\
\hline
\end{tabular}

E.5 Strict law enforcement must be encouraged.

\begin{tabular}{|l|l|l|}
\hline Strict law enforcement & must & be encouraged. \\
\hline Mood & & Residue \\
\hline Goal & Proc: Material \\
\hline
\end{tabular}

In E3, Jokowi states that the "Regulations that are not compatible with the recent development must be removed." Again, we see that in 'regulation' there must be 'someone/authority who regulates (regulator)' which points out to those who are legitimated in law and regulation-making. But since the Actor of 'law-maker' is not mentioned in the clause, there a possibility to the non-authoritative party to count themselves as the Actor 'to remove' the regulation. But first, those must take for granted that the incompatible regulation does exist even though there is no rigid measurement of how regulation is seen as incompatible. To this point, the chance to use the symbolic power (Pierre Bordieu, 1977) in pursuing a group interest by removing a regulation that is seen unmatch to the interest of some groups is possible. We can take the example of a late feud among Indonesians on the draft of the law for Corruption Eradication Commission proposed in 2019 which raises many protests among the citizens and results in mass movements across the country.

In E4, President Jokowi states, "Rights of the citizens for personal data must be 
protected." At the surface, this statement is just fine in the term that the privacy of individuals is not for the public to be consumed. Therefore, it must be protected. The question raised from this statement is on the agent who must play the role to protect the data and what data is meant to be protected. In the era of the internet, people use various media to communicate and to consolidate their interests. If Jokowi is firm in saying (E5) "Strict law enforcement must be encouraged," then the regulation should be made to not only protect the data, but the greater good of the people as to build an 'Advance Indonesia' must count on the interest of the nation. There must be a fine line to differentiate what data belongs to citizens' private life, and what data is counted as a threat to the nation.

\section{The Quest for Characterizing Indonesia}

People use language not only to represent society but to construe what an ideal reality should be in their point of view. The grammar of the Relational Process is a device to give attributes to the things that exist. Therefore it is essential to see what Jokowi puts as an attribute on the matter he points as important to the discourse of an 'Advanced Indonesia'. Here on the table, the researchers collect the high modulated clauses, which are combined with the act of attributing.

Table 7. Must + Relational Process Attributive and Having

\begin{tabular}{|c|c|c|c|}
\hline Carrier & $\begin{array}{c}\text { Process } \\
\text { (Relational } \\
\text { Attributive\& } \\
\text { Having) }\end{array}$ & Attribute & Circumstantial \\
\hline $\begin{array}{l}\text { We, Humanity, } \\
\text { The people, } \\
\text { Our products, } \\
\text { Our talents, } \\
\text { Our education, } \\
\text { Works of the } \\
\text { Government, } \\
\text { works of } \\
\text { executive } \\
\text { bureaucrats, } \\
\text { works of } \\
\text { supervisory } \\
\text { bureaucrats, }\end{array}$ & be, become & $\begin{array}{l}\text { Respective and } \\
\text { ready, vigilant, } \\
\text { better than the } \\
\text { others, the soul of } \\
\text { Indonesian foreign } \\
\text { policy, vigilant and } \\
\text { aware of the risk, } \\
\text { dare, able, } \\
\text { internationally } \\
\text { reputable and } \\
\text { acclaimed, } \\
\text { responsive and } \\
\text { open, ready, result- } \\
\text { oriented, the } \\
\text { courage }\end{array}$ & $\begin{array}{l}\text { Cause: to face cyber wars, intolerance, } \\
\text { radicalism, and terrorism, to anything } \\
\text { that may pose a threat to our } \\
\text { sovereignty, to escape the curses of } \\
\text { natural resources, to begin now, to flood } \\
\text { both regional and global markets, to } \\
\text { global changes, to face the threats posed } \\
\text { by cybercrimes, including the crime of } \\
\text { data misuse; Accompaniment: as well as } \\
\text { to face threats of other crimes; Location: } \\
\text { both at home and abroad, which } \\
\text { threaten our unity and integrity as a } \\
\text { nation }\end{array}$ \\
\hline $\begin{array}{l}\text { Our } \\
\text { businessmen } \\
\text { and state- } \\
\text { owned } \\
\text { enterprises }\end{array}$ & have & the courage & Cause: to become world-class players. \\
\hline
\end{tabular}

Halliday (2004, p. 210) states that "Relational clauses serve to characterize and to identify". By attaching the attribute to the carrier, usually, the speaker means to explicate the character of the carriers. However, with the addition of High Modality 'must', it changes the whole meaning from merely representing a demanding attitude. Instead of declaring the existing condition, Jokowi is expecting the carriers to possess the prescribed qualities to achieve the goal of pursuing an 'Advance Indonesia'.

What Jokowi demands to be the characters of an 'Advanced Indonesia' as first is the readiness and attentiveness of the people to the issue of cyber wars, intolerance, radicalism, and terrorism as they threat Indonesia's sovereignty. Second is that the economy and education sectors are expected 
to be responsive and open to global challenges. These matters are achievable only if those are supported by the way government, executive bureaucrats, supervisory bureaucrats work.
All looks to be put in place until an eager listener tries to criticize how those things are possibly implemented. Take a look at these excerpts:

\section{E7. We must be better than the others.}

\begin{tabular}{|l|l|l|l|}
\hline We & must & be & better than the others. \\
\hline Mood & & Residue & \\
\hline Carrier & & Proc: Relational: Attributive & Attribute \\
\hline
\end{tabular}

E8. Works of the Government, works of executive bureaucrats, works of supervisory bureaucrats must be result-oriented.

\begin{tabular}{|l|l|l|l|}
\hline $\begin{array}{l}\text { Works of the Government, works of } \\
\text { executive bureaucrats, works of } \\
\text { supervisory bureaucrats }\end{array}$ & be & $\begin{array}{l}\text { result- } \\
\text { oriented. }\end{array}$ \\
\hline Mood & & Residue & Proc: Relational: Attributive \\
\hline Carrier
\end{tabular}

In E7, it is 'we' as the Carrier and 'better than the others' as the Attribute. If 'we' here is the nation of Indonesia, the 'others' are other countries specifically the neighboring countries. This statement might sound like a given motivation to Indonesia to perform 'better' as a developing country in competition towards other countries. However, to compete for means there is a rule as the indicator to base our reasoning before saying that we are already better than others or otherwise. If the indicator is not set to clear, this nation is just competing in a wild unruled game.

Furthermore, in E8, it is said that "Works of the Government, works of executive bureaucrats, works of supervisory bureaucrats must be result-oriented." The problem is on the word 'result'. Normally, the result is gained by a work done, and to achieve the expected result, the work must be done in a formulated way that guarantees the result itself. The flow of logic is then violated if 'result' is seen as the mean of measurement. It is like saying that if there is no thief caught by the police means that the country is totally safe where in fact the thief is still there making crimes. However, this statement is balanced with Jokowi's previous statement saying "Therefore, it is management,

governance, and system that must be developed" which sounds more like a commitment that the future government should put effort to make it true.

\section{Conclusion}

From the discussion on the findings, the researchers conclude that Jokowi actually directs the people to act and behave in accordance with his will in order to support the realization of the 'Advanced Indonesia'. This is shown by the use of High Modality 'must' that appears frequently throughout the speech indicating that he uses the power to instruct the people. His speech, however, is not producing a final meaning for a question is open on what he means as the Actor or the agent who is seen as capable to do all the command. It is because, firstly, the inclusive 'we' filling a subject position in the clauses with modal 'must' gives no clear direction of who is supposed to be accountable on the demanded tasks.

Secondly, hidden Actor in the Nominalization and Passive Voice does not offer a clear command to those who are responsible for the issues stated in the speech. Thirdly, the discourse that he builds is also focused to re-characterize Indonesia as seen in the use of Relational Processes of Attributive combined with the high modality. Halliday mentions that 'the internal organization of language is not arbitrary but embodies a positive reflection of the functions that language has evolved to serve in the life of social man' (1976, p. 26). 
Despite the style of the political speech which does not enable the speaker to explain all matters in detail for its limited space and time, this writing invites the readers to be aware of the choice in the language used in the text. Just like Bourdieu claims a speech is political if the author has specified the capable actor or a group of actors/agents that commit to carry out the action so that a speech can be defined equivalent to an act (1982, p. 190).

Every social practice only comes to realization when there is a mutual understanding between the social agents who are both the sender and the receiver of the message. Thus, between the transmission of the message, research with Systemic Functional Linguistics and Critical Discourse Analysis presents to bridge the power imbalance between those who rule and the people that are ruled.

\section{References}

Anggraini, N. 2018. Transitivity Process And Ideological Construction Of Donald Trump's Speeches. (Undergraduate thesis). UIN Surabaya, Surabaya.

Bourdieu, P. (1982). Language and Symbolic Power. Edited by John B. Thompson. Cambridge: Polity Press.

Eggins, S. (2004). An Introduction to Systemic Functional Linguistics. $2^{\text {nd }}$ Edition. London: MPG Books Ltd, Bodmin, Cornwall.

Fairclough, N. (2003). Analysing Discourse: Textual analysis for Social Research. London: Routledge.

Fairclough, N. (2010). Critical Discourse Analysis, The Critical Study of Language. $2^{\text {nd }}$ Edition. London: Routledge.

Fontaine., L. (2013). Analysing English Grammar: A systemic Functional Introduction. Cambridge: Cambridge UP.
Gee, J. P. (2014). How to do Discourse Analysis: A Toolkit. New York: Routledge.

Gee, J. P. (2018). Introducing Discourse Analysis: From Grammar to Society. New York: Routledge.

Halliday, M. A. K. (1976). "Functions and Universals." System and Function in Language. Edited by G. Kress. London: Oxford University Press.

Halliday, M. A. K. (2003). On Language and Linguistics. Edited by Jonathan Webster. London: Continuum.

Halliday, M. A. K. (2004). An Introduction to Functional Grammar. $3^{\text {rd }}$ Edition. London: Arnorld.

Hart, C. (2014). Discourse, Grammar and Ideology: Functional and Cognitive. Perspectives. London: Bloomsbury Publishing Plc.

Hasanah, U., Alek, \& Hidayat, D. N. (2019). A Critical Discourse Analysis of Kim Namjoon's (RM's) Speech. Jurnal Humaniora Teknologi, 5(5), 16-26. https://doi.org/10.34128/jht.v5i2.60

Isti'anah, A. (2012). Ideologies Inhosni Mubarak's and Muammar Qaddafi's Translated Speeches: Critical Discourse Analysis (Graduate Thesis). Universitas Sanata Dharma, Yogyakarta.

Jorgensen, M. \& Philips, L. (2004). Discourse Analysis as Theory and Method. London: Sage.

Loyal, S. (2017). Bourdieu's Theory of The State: A Critical Introduction. New York. Palgrave.

Meurer, J. (2004). "Role Prescriptions and Social Practices." Systemic Functional Linguistics and Critical Discourse Analysis (Edited by LynneYoung and Claire Harrison). London: Continuum.

Widodo, J. (2019). State Address of The President of the Republic of Indonesia 
on the Occasion of the 74th Anniversary of the Proclamation of Independence of the Republic of Indonesia Before the Joint Session of the Regional Representatives Council of the Republic of Indonesia and the House of Representatives of the Republic of Indonesia. Retrieved from https://setkab.go.id/en/state-addressof-the-president-of-the-republic-ofindonesia-on-the-occasion-of-the-74thanniversary-of-the-proclamation-ofindependence-of-the-republic-ofindonesia-before-the-joint-session-ofthe-r/. Accessed on 3 September 2019.

Wodak, R. \& Meyer, M. (2000). "Critical Discourse Analysis: History, Agenda, Theory, and Methodology." Methods of Text and Discourse Analysis (Translated by Bryan Jenner). London: SAGE Publications. 